\title{
Faktor Penyebab Terjadinya Penularan Penyakit Flu Burung pada Manusia di Kota Pekanbaru dan Kabupaten Pelalawan
}

\section{Occurrence of Disease Transmission Causes Avian Influenza at Humans in Pekanbaru City and Pelalawan Regency}

\author{
Donal* Zainal Abidin**
}

*Program Studi Ilmu Lingkungan Universitas Riau**STIKes Hang Tuah Pekanbaru

\begin{abstract}
Abstrak
Kota Pekanbaru dan Kabupaten Pelalawan ditetapkan sebagai wilayah Kejadian Luar Biasa (KLB) flu burung setelah terjadi kasus Flu Burung yang menyebabkan kematian warga. Terjadinya KLB dipengaruhi oleh faktor Lingkungan, Perilaku dan Pelayanan Kesehatan. Dilihat dari tingkat kegawatannya kasus ini harus segera diantisipasi sehingga tidak semakin meluas dan meresahkan masyarakat. Oleh karena itu perlu diketahui faktor yang cenderung mempengaruhi terjadinya penularan Flu Burung, sehingga masyarakat bisa lebih waspada terhadap segala kemungkinan penularan Virus H5N1. Rancangan Penelitian adalah Dekriptif Eksploratif dalam bentuk studi kasus. Subjek penelitian adalah semua penderita positif Avian Influenza dan pengelola program flu burung Kota Pekanbaru dan Kabupaten Pelalawan, yang dipilih secara purposive sampling. Hasil penelitian menunjukkan faktor lingkungan yang dominan cenderung terjadi pada keluarga yang melakukan aktivitas beternak unggas dan kasus ini cepat diatasi. Upaya penanggulangan oleh pemerintah untuk kasus yang berhubungan dengan unggas sudah mempunyai Standar Opersional Prosedur yang jelas sehingga kasus cepat teratasi. Faktor perilaku yang dominan mempengaruhi terjadinya kasus flu burung ialah pada keluarga yang mempunyai kebiasaan menggunakan pupuk kotoran unggas dan kebiasaan orang tua membawa anaknya ketempat beresiko terjadinya flu burung.
\end{abstract}

Kata kunci : KLB, Studi Kasus, Faktor Lingkungan, Faktor Perilaku

\begin{abstract}
Pekanbaru City and Pelalawan Regency has specified as avian flu case extraordinary occurance regional after there were happend as Avian flu case that made citizen death. It happened due to various factors; Environment, habits and health services. It is important to know factors which deal with avian flu infection at human in Pekanbaru City and Pelalawan Regency which can cause death. Thereby, people can be more attentive to all possibility of H5N1 Virus Infection. Descriptive Explorative is used as a method to understand the issues raised. The population of this reseach is all positive patients affected avian influenza, distefully the information obtained from selected purposively. This research showed that the main factor affecting avian influenza was environmental factor, from activities doing poultry farming. This case quickly overcomes which reducing the risks of death case. Goverment is suggested to aware with poultry hace which has to occupies standard operating procedure enable this case quickly overcame. While for the dominant influence of habits factor, tend to became of that family that having habit to use dist poultry manure for plant flower activity, dispitefully, the parent habits that brough their child the region which risk of avian influenza case.
\end{abstract}

Key word : Outbreaks, Case Studies, Environmental Factors, Behavioral Factor

\section{Pendahuluan}

Flu burung adalah penyakit menular yang disebabkan oleh virus influenza tipe A dan ditularkan oleh unggas. Penyakit flu burung yang ditularkan oleh virus Avian Influenza jenis $\mathrm{H} 5 \mathrm{~N} 1$ pada unggas dikonfirmasikan telah terjadi di Republik Korea, Vietnam, Jepang, Thailand, Komboja, Taiwan, Laos, China, Indonesia dan Pakistan. Sumber virus diduga berasal dari migrasi burung dan tranportasi unggas yang terinfeksi. (Balitbang Depkes, 2005).

Indonesia pada bulan Januari 2004 pun dikejutkan dengan kematian ayam ternak yang luar biasa ( terutama di Bali, Jabotabek, Jawa Timur, Jawa Tengah, dan sejumlah daerah lainya). Awalnya kematian tersebut disebabkan virus new castle, namun konfirmasi terakhir oleh Departemen Pertanian disebabkan oleh virus flu burung (Avian Influenza). Jumlah unggas yang mati akibat wabah penyakit flu burung di 10 provinsi di Indonesia sangat besar yaitu 
3.842.275 ekor (4,77\%). (Balitbang Depkes,2005).

Saat ini hampir disetiap daerah di Indonesia selalu ditemukan kasus flu burung, termasuk Provinsi Riau. Data kasus flu burung di Provinsi Riau sampai dengan desember 2008, jumlah kasus suspek adalah 96 kasus dan jumlah kasus konfirmasi sebanyak 7 kasus. Kasus suspek adalah kasus flu burung yang menunjukkan gejala yang mirip dengan flu burung namun belum dilakukan pemeriksaan laboratorium sedang kasus konfirmasi adalah kasus flu burung yang menunjukkan gejala penyakit flu burung dan hasil pemeriksaan laboratorium menunjukkan hasil positif terinfeksi virus flu burung H5N1.

Gambar 1. Kasus Suspek \& Konfirmasi Avian Influenza Di Kab/Kota Se Prov Riau S/D Des 08

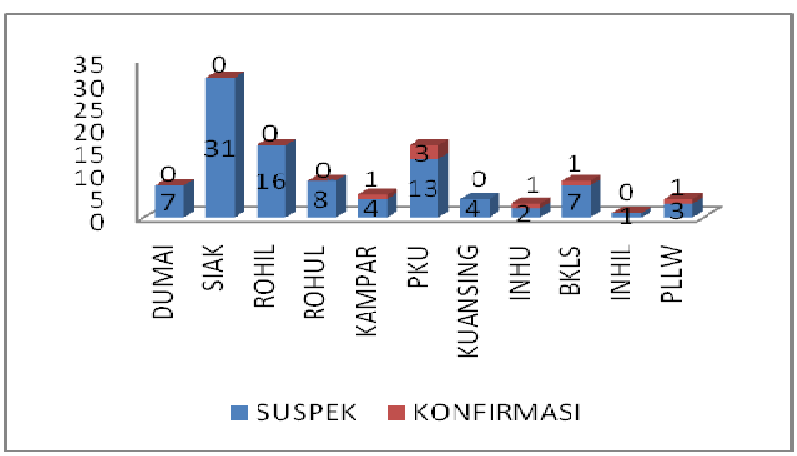

Diketahui bahwa dari 7 kasus positif flu burung di Provinsi Riau, jumlah kematian mencapai 5 orang. Keadaan ini menyebabkan pemerintah setempat menetapkan Provinsi Riau sebagai daerah Kejadian Luar Biasa (KLB) flu burung. (Dinkes Pekanbaru Riau, 2009).

Terdapat 5 wilayah yang kemudian ditetapkan sebagai wilayah kejadian luar biasa (KLB) di Provinsi Riau, yaitu Kabupaten Kampar, Duri (Kabupaten Bengkalis), Kota Pekanbaru, Kab. Pelalawan dan Indragiri Hulu. Dari 12 kecamatan yang ada di Pekanbaru, 7 kecamatan diantaranya juga ditetapkan sebagai wilayah KLB. Langkah ini juga dilakukan setelah terjadi kematian 2 orang warga kota Pekanbaru akibat flu burung. Namun begitu masih ada penderita flu burung yang masih hidup yang ditangani dengan cepat dengan pemberian tamiflu : 1 orang di kota Pekanbaru dan 1 orang di kabupaten Pelalawan.( Dinas Kesehatan Provinsi Riau, 2009)

Ditilik dari tingkat severitynya atau tingkat kegawatannya, kasus flu burung ini harus bisa diantisipasi sedemikian rupa sehingga kasusnya tidak semakin meluas yang bisa menimbulkan keresahan yang tinggi di tengah masyarakat. Supaya bisa dilakukan langkah antisipasi yang tepat, perlu diketahui faktor yang berhubungan dengan flu burung pada manusia di Kota Pekanbaru yang mengakibatkan kematian hingga mencapai $83,3 \%$. Dengan demikian masyarakat bisa lebih waspada terhadap segala kemungkinan penularan virus $\mathrm{H} 5 \mathrm{~N} 1$ ini. Tujuan dari penelitian ini adalah diketahuinya faktor-faktor penyebab terjadinya penularan Avian Influenza kemanusia di Kota Pekanbaru dan Kabupaten Pelalawan.

\section{Metode}

Rancangan penelitian menggunakan pendekatan Deskriptif Eksploratif, yang dilakukan di kota Pekanbaru dan kabupaten Pelalawan tahun 2009 dengan menggunakan teknik wawancara mendalam dengan semua penderita positif Avian Influenza serta pengelola program flu burung di Dinas kesehatan Kota Pekanbaru dan Dinas Kesehatan Kabupaten Pelalawan. Instrumen penelitian menggunakan pedoman wawancara, pedoman observasi dan hygrometer untuk mengukur kelembapan. Data dianalisis dengan menggunakan analisis kualitatif. Validitas data dalam penelitian menggunakan metode triangulasi sumber dan teori. Informasi yang diperlukan adalah informasi tentang lingkungan, perilaku individu, dan penanggulangan avian influenza.

\section{Hasil}

\section{Lingkungan}

Lingkungan adalah segala sesuatu yang berada disekitar informan yang mempengaruhi baik secara langsung maupun tidak langsung terhadap kesehatan informan. Informan terdiri dari 5 orang keluarga penderita flu burung di Kota Pekanbaru dan Kabupaten Pelalawan

\section{Kondisi Tempat Tinggal}

Dari hasil observasi terhadap kondisi tempat tinggal penderita menunjukkan bahwa kondisi tempat tinggal penderita flu burung pada umumnya dalam keadaan bersih.

2. Jarak Tempat Tinggal Dengan Unggas

Dari hasil observasi terhadap jarak tempat tinggal penderita dengan unggas menunjukkan bahwa tiga informan jarak tempat tinggal penderita dekat dengan unggas, sedangkan dua informan lagi jarak tempat tinggal penderita jauh dari unggas.

3. Jumlah Unggas

Berdasarkan hasil observasi terhadap jumlah unggas yang ada disekitar tempat tinggal penderita menunjukkan bahwa jumlah unggas yang ada disekitar tempat tinggal penderita berjumlah 5 ekor pada seorang informan, pada dua orang informan lagi berjumlah 12-15 ekor, sedangkan pada dua orang informan lagi tidak ada unggas sama sekali disekitar tempat tinggal mereka. 
4. Kondisi Kandang Unggas

Berdasarkan hasil observasi terhadap kondisi kandang menunjukkan bahwa dari ketiga informan yang tempat tinggal mereka dekat dengan kandang, kondisi kandang pada umumnya kotor.

5. Keadaan Udara

Dari hasil observasi terhadap keadaan udara disekitar tempat tinggal penderita pada umumnya dalam keadaan kering.

6. Keadaan Tanah

Dari hasil observasi terhadap kondisi tanah menunjukkan bahwa empat orang informan tinggal pada kondisi tanah yang kering dan hanya satu informan yang sebagian kondisi tanah tempat tinggalnya dalam keadaan lembab dan berair

7. Kotoran Unggas

Berdasarkan hasil observasi menunjukan bahwa kotoran unggas terdapat pada tempat tinggal tiga informan yang memiliki kandang ayam disekitar tempat tinggal mereka.

8. Perlindungan Diri (Proteksi)

Dari hasil observasi menunjukkan hanya satu orang informan yang memiliki alat pelindung diri dalam melakukan kegiatan yang berhubungan dengan unggas sedang informan lain tidak melakukan kegiatan berhubungan dengan unggas.

9. Sumber Makanan Unggas

Berdasarkan hasil observasi menunjukkan hanya satu informan yang terdapat sumber makanan unggas disekitar tempat tinggal sedangkan informan yang lain tidak terdapat sumber makanan unggas.

10. Burung Liar di sekitar tempat tinggal

Dari hasil observasi menunjukkan bahwa pada umumnya di sekitar tempat tinggal penderita tidak terdapat unggas liar.

\section{Faktor Perilaku Penderita}

1. Pengetahuan Keluarga Penderita Tentang Flu Burung

Tingkat pengetahuan keluarga penderita tentang flu burung umumnya didapat berdasarkan pengalaman. Seperti yang disampaikan informan berikut ini mengenai bagaimana terjadinya penularan flu burung pada manusia :

“...Berdasarkan hasil pemeriksaan beberapa sampel, penyebabnya pupuk yang dipakai untuk menanam bunga, atau kotoran burung liar..." (Wawancara tanggal 23 Juli 2009, YY,47)

“...Berdasarkan mencari bebek, anak saya ikut. Pada waktu itu ia berdiri dekat dengan tempat pembuangan kotoran kandang ayam..."

(wawancara tanggal 23 Juli 2009, H. 38)
Pertanyaan berikutnya tentang gejala flu burung pada manusia dan unggas, informan menjawab sebagai berikut :

"...gejalanya demam tinggi, biasanya turun, malah makin lama makin tinggi, badan makin lemah, ngak mau makan, ada kelainan paruparu... pada ayam saya tidak melihat..."

(wawancara tanggal 23 Juli 2009, H. 38)

2. Sikap Keluarga Penderita Terhadap Kasus Flu Burung

Sikap keluarga penderita terhadap kasus flu burung diketahui dengan melihat tanggapan mereka terhadap peraturan daerah melarang memelihara unggas tanpa dikandangkan dan dilarang disekitar tempat tinggal, sebagian besar informan bersikap setuju, hanya seorang informan yang kurang setuju. Hal ini dapat dilihat dari wawancara dengan informan tersebut

“...kalau pemerintah tidak membenarkan beternak selagi masih bisa ditawar, kehidupan dikampung kalau saya tidak ternak ayam, tetap membutuhkan telur..."

(wawancara tanggal 14 Juli 2009, S. 40.)

3. Tindakan Keluarga Penderita Terhadap Kasus Avian Influenza

Tindakan keluarga penderita diketahui dengan menanyakan kepada informan yang masih melakukan kegiatan berternak. Pertanyaan ditanyakan diantaranya ialah; Bagaimana caranya agar unggas tidak tertular flu burung? Jawaban informan sebagai berikut :

“...Ternak boleh tetapi kandang harus selalu dibersihkan, sekali seminggu disiram dengan bahan bekas cucian, kalau perlu dekat kandang dibuat api unggun..."

(Wawancara tanggal 14 Juli 2009, S, 40)

Pertanyaan selanjutnya menanyakan bagaimana agar kita tidak tertular flu burung dari unggas? Jawaban dari informan atas pertanyaan tersebut :

“... ayam sakit jangan dimakan, pakai sarung tangan, masukan kelubang lalu dibakar, jangan menggunakan pupuk kandang..."

(Wawancara tanggal 14 Juli 2009,S.40)

\section{Faktor Penanggulangan Flu Burung}

Informan penelitian terdiri dari 4 orang kepala pukesmas, penanggung jawab program, penanggung jawab program penanggulangan flu burung diwilayah Kota Pekanbaru dan Kabupaten Pelalawan, serta informan triangulasi terdiri dari 4 orang yang berasal dari dinas kesehatan dan dinas peternakan di Kota Pekanbaru dan Kabupaten Pelalawan. 
1. Pengorganisasian

Berdasarkan hasil wawancara pengorganisasian di dalam penanganan flu burung, pemerintah daerah sudah memiliki tim-tim yang akan menangani apabila terjadi kasus flu burung, dari unit terkecil di masyarakat hingga ke tingkat kabupaten/kota, hal ini sejalan dengan yang disampaikan oleh informan triangulasi dari dinas kesehatan maupun dari dinas pertanian/ peternakan kabupaten / kota.

\section{Kebijakan / Peraturan}

Dari hasil wawancara mendalam terhadap informan menunjukkan bahwa baik Kota Pekanbaru maupun Kabupaten Pelalawan belum memiliki peraturan daerah yang mengatur tentang penatalaksanaan pemeliharaan unggas yang diharapkan mampu mengatasi terjadi kasus flu burung di masyarakat, namun informan juga menjelaskan bahwa sudah memiliki Standar Operations Prosedur (SOP) dalam penanganan kasus flu burung, hal ini sama dengan hasil wawancara pada informan triangulasi. Seperti yang dikatakan informan sebagai berikut:

“... Jika ditemukan suspect flu burung maka tim akan melacak ke alamat suspect, dan melakukan wawancara dengan anggota keluarga, mendata 20 KK disekitar lokasi rumah suspect untuk dipantau kesehatanya selama 21 hari, mengirim laporan $W$ $1=1 \times 24$ jam ke dinas kesehatan kota, bila ada warga di sekitar rumah suspect yang diduga terkena ILI : di berikan Tamiflu $<2 \times 24$ jam selanjutnya dirujuk Ke RSUD Arifin Achmad..."

(Wawancara Tanggal 11 Juli 2009, RM, 26)

3. Anggaran

Berdasarkan hasil wawancara mendalam dengan informan terlihat bahwa biaya yang dibutuhkan untuk penanganan flu burung bervariasi , besarnya biaya yang dibutuhkan dalam penanganan flu burung sangat ditentukan dimana kasus flu burung terjadi. Kegiatan-kegiatan penanganan kasus Avian Influenza berupa penyelidikan epidemiologi, surveilans dan rujukan pasien. Sedangkan tentang ketersedian anggaran untuk mengatasi kasus Avian Influenza pada umumnya informan mengatakan tidak ada ketersedian dana untuk penanganan kasus Avian Influenza, hanya satu informan yang mendapat bantuan dari WHO.

Hasil dari informan triangulasi menyampaikan biaya penanggulangan Avian Influenza anggaranya di alokasikan di dinas kesehatan dalam bentuk kegiatan penanggulangan KLB penyakit dan tidak dialokasikan di pukesmas.
Sebagaimana yang disampaikannya sebagai berikut :

“... Seтua biaya penanggulangan penyakit yang dikatagorikan $K L B$ anggaranya tersedia dalam $A P B D$ kabupaten tiap tahun dalam bentuk kegiatan penanggulangan KLB penyakit..."

(Wawancara tanggal 16 Juli 2009, AS,45)

4. Hambatan

Dalam hal mengatasi terjadinya kasus flu burung, pemerintah daerah masih mengalami hambatanhambatan, berikut jawaban informan tentang hambatan yang dialami dalam penanggulangan flu burung :

"...masyarakat masih sulit menerima dan melaksanakan upaya pencegahan flu burung (seperti : mengandangkan unggas, memisahkan kandang dari rumah, membersihkan kandang, menggunakan alat pelidung diri...)"

(Wawancara tanggal 22 Juli 2009, RM,26)

Begitu pula dari informan Triangulasi, masih ada hambatan lain dari pihak pemerintah sendiri, seperti hasil wawancara mendalam berikut :

"...Minimnya dukungan pemerintah dalam penanggulangan AI, khususnya alokasi anggaran, belum optimalnya kinerja tm, rendahnya koordinasi lintas sektor..."

(Wawancara tanggal 16 Juli 2009, AS,45)

Berdasarkan hasil wawancara mendalam dengan informan menunjukkan bahwa hambatanhambatan tidak hanya terjadi dimasyarakat tetapi juga di pemerintah daerah sendiri. Hambatan dimasyarakat yang ditemukan adalah masih sulitnya mengubah perilaku masyarakat dalam penerapan PHBS, sedangkan dari pemerintah sendiri adalah minimnya dukungan pemerintah dalam penanggulangan AI, Khususnya alokasi anggaran yang mengakibatkan kinerja tim tidak optimal.

\section{Pembahasan}

\section{Faktor Lingkungan}

Perubahan lingkungan global akan mempengaruhi jenis penyakit yang muncul sebab keadaan lingkungan sangat besar pengaruhnya terhadap kesehatan manusia. Di dalam lingkungan yang sesuai, peyebab penyakit dapat ditularkan dari manusia ke manusia, dari hewan ke hewan atau dari manusia ke hewan. Keadaan - keadaan lingkungan seperti kondisi tempat tinggal, jarak tempat tinggal dengan unggas, jumlah unggas, kondisi kandang, keadaan udara, keadaan tanah, kotoran unggas, perlindungan diri (Proteksi), sumber makanan unggas, 
dan adanya burung liar sekitar tempat tinggal sangat berperan.

Faktor lingkungan yang sangat dominan mempengaruhi penularan Avian Influenza cenderung terjadi pada keluarga yang melakukan aktivitas berternak unggas atau terpapar unggas, tempat tinggal mereka berada sangat dekat dengan kandang unggas $(<25$ meter). Jumlah unggas masih dalam jumlah kecil ( $<20$ ekor). Kondisi kandang kotor, masih terdapat kotoran unggas disekitar tempat tinggal. Keadaan udara dan tanah pada umumnya kering, tidak ada burung/unggas liar disekitar tempat tinggal.

\section{Faktor Perilaku}

1. Pengetahuan Keluarga Penderita Tentang Flu Burung

Berdasarkan pengalaman dan penelitian terbukti bahwa perilaku yang didasari oleh pengetahuan lebih permanen daripada perilaku yang tidak didasari oleh pengetahuan. Berdasarkan hasil wawancara mendalam terhadap informan tentang apa yang dimaksudkan flu burung dan bagaimana terjadinya penularan flu burung, gejala flu burung pada manusia dan unggas, informan pada umumnya mampu menjawab berdasarkan pengalaman mereka dalam menangani kasus flu burung yang menimpa keluarga mereka. Sebelum keluarga mereka terkena kasus flu burung pada dasarnya pengetahuan mereka tentang flu burung.

2. Sikap keluarga penderita terhadap kasus flu burung

Sikap merupakan reaksi atau respon yang masih tertutup dari seseorang terhadap suatu stimulus atau obyek. Sikap secara nyata menunjukkan konotasi adanya kesesuaian reaksi stimulus tertentu. Sikap informan mengenai penerapan peraturan daerah melarang memelihara unggas tanpa dikandangkan dan dilarang disekitar tempat tinggal, sebagian besar informan setuju.

3. Tindakan Keluarga Penderita Terhadap Kasus Avian Influenza

Tindakan informan berdasarkan wawancara mendalam dan pengamatan hanya tinggal satu informan yang masih melakukan kegiatan ternak. Bila dilihat tindakan yang diambil untuk mencegah agar tidak tertular ke manusia, informan ini mengambil tindakan yang disarankan yaitu : apabila ada unggas yang sakit langsung digali lubang, pakai sarung tangan, diikat masukan kelubang lalu dibakar.

Berdasarkan hasil Riset Kesehatan Dasar Tahun 2007 menunjukkan penduduk yang pernah mendengar tentang flu burung di Provinsi Riau sebanyak $74 \%$, diantara mereka $77,2 \%$ memiliki pengetahuan yang benar, 87,7\% memiliki sikap yang benar. Untuk Kota Pekanbaru yang pernah mendengar $88,3 \%$, berpengetahuan benar $68,8 \%$ dan yang bersikap benar $91,7 \%$ sedangkan untuk Kabupaten Pelalawan yang pernah mendengar $68,4 \%$, berpengetahuan benar $84,1 \%$ dan yang bersikap benar $92,6 \%$ (Depkes RI, 2008).

\section{Faktor Penanggulangan Flu Burung}

1. Pengorganisasian

Pemerintah daerah sudah memiliki SKPD( Satuan Kerja Perangkat Daerah) yang bertugas untuk menangani kejadian flu burung. Disamping SKPD tersebut juga dibentuk tim, untuk saling berkoordinasi dalam penanggulangan Avian Influenza. Struktur tim yang telah terbentuk diharapkan mampu mengatasi terjadinya kasus flu burung, yang terdiri dari unsur kesehatan, peternakan / pertanian, perdagangan, perhubungan dan Pemda sendiri. Tim yang dari unit terkecil dimasyarakat hingga ke kabupaten/kota sudah mempunyai tugas yang jelas. Dengan pembagian tugas yang jelas tersebut, tim yang sudah terbentuk diharapkan dapat meningkatkan kinerjanya dalam penanganan flu burung.

\section{Kebijakan / Peraturan}

Kebijakan/peraturan sangat diperlukan dalam upaya mengatur penatalaksanaan unggas. Berdasarkan hasil wawancara menunjukkan bahwa belum ada peraturan daerah yang mengatur penatalaksanaan pemeliharaan unggas, tempat penjualan dan tempat pemotongan ayam dan unggas dalam rangka mewaspadai kasus flu burung. Kebijakan yang telah diambil masih sebatas pembentukan tim penanganan flu burung. Pemerintah daerah yang sudah menerapkan Perda mengenai pemeliharaan unggas adalah DKI Jakarta. Namun penerapan Perda ini menimbulkan pro kontra di masyarakat. kebijakan yang sudah diambil Pemerintah Daerah Riau sudah mengeluarkan Instruksi Gubernur No. 2 tahun 2006, tentang penatalaksanaan unggas, tempat penjualan, dan pemotongan ayam dalam rangka mewaspadai wabah AI di Provinsi Riau.

Dalam penerapan Standart Operation Prosedur (SOP) dalam penanganan Avian Influenza informan pada umumnya sudah mempunyai prosedur tetap. Hal ini sangat berguna untuk menghindari kesalahan-kesalahan didalam menegakkan diagnosa penyakit flu burung, serta mempercepat petugas dalam mengambil tindakan apabila terjadi kasus flu burung.

\section{Anggaran}

Dukungan angaran dalam upaya mengatasi terjadinya kasus flu burung sangatlah terbatas, prioritas anggaran lebih ditujukan kapada program 
penurunan AKI dan AKB. Kegiatan-kegiatan penanganan kasus Avian Influenza berupa penyelidikan epidemiologi, surveilans dan rujukan pasien. Besarnya biaya yang dibutuhkan dalam penanganan flu burung sangat ditentukan dimana terjadinya kasus flu burung.

Dalam hal ketersedian anggaran informan mengatakan tidak ada ketersedian anggaran untuk penanganan kasus Avian Influenza, hanya satu pukesmas yang mendapat bantuan dari WHO untuk kegiatan pelatihan, sosialisasi, pemetaan dan SMD. Biaya penanggulangan Avian Influenza, dialokasikan di dinas kesehatan dalam bentuk kegiatan penanggulangan KLB penyakit.

4. Hambatan

Usaha-usaha preventif yang dilakukan oleh pukesmas dalam penaggulangan Avian Influenza sudah baik, kegiatan berupa penyuluhan, koordinasi lintas program dan lintas sektor dengan membentuk tim tanggap flu burung. Hambatan-hambatan didalam penanggulangan Avian Influenza pada umumnya informan mengatakan sulitnya merubah perilaku masyarakat dalam penerapan PHBS dan sulitnya menerapkan tindakan pencegahan terjadinya flu burung berkaitan dengan ekonomi. Namun begitu disamping dari hambatan yang ditemukan dimasyarakat masih ada hambatan lain di pihak pemerintah sendiri.

\section{Kesimpulan}

\section{Faktor Lingkungan}

Faktor lingkungan yang sangat dominan mempengaruhi penularan Avian Influenza cendrung terjadi pada keluarga yang melakukan aktivitas berternak unggas atau terpapar unggas, tempat tinggal mereka berada sangat dekat dengan kandang unggas $(<25$ meter). Jumlah unggas masih dalam jumlah kecil $(<20$ ekor). Kondisi kandang kotor, masih terdapat kotoran unggas disekitar tempat tinggal. Keadaan udara dan tanah pada umumnya kering, tidak ada burung/unggas liar disekitar tempat tinggal.

\section{Faktor Perilaku Penderita}

Faktor perilaku penderita turut mempengaruhi terjadinya penularan Avian Influenza, dimana tingkat pengetahuan penderita tentang flu burung masih kurang pada saat terjadinya kasus, setelah terjadinya kasus, pengetahuan tentang flu burung

sudah lebih baik, informasi diberikan oleh petugas pukesmas dan dinas pertanian dalam bentuk penyuluhan. Semua informan memiliki sikap yang positif terhadap penanganan flu burung, dilihat dari sikap informan terhadap pemerintah jika menerapkan peraturan dan usaha-usaha yang dilakukan pemerintah.
Ditinjau dari tindakan keluarga penderita, Sebagian besar informan sudah melaksanakan tindakan sesuai dengan kesehatan.

\section{Faktor Upaya penanggulangan Avian Influenza}

Upaya penangggulangan untuk kasus di Kota Pekanbaru dan Kabupaten Pelalawan sudah mempunyai standar operasional prosedur yang jelas dan struktur tim yang cukup baik dalam penanggulangan Avian Influenza baik pada manusia maupun unggas. Semua informan menyatakan pemerintah daerah belum memiliki peraturan daerah dalam penanganan flu burung namun pemerintah provinsi telah mengeluarkan instruksi gubernur dan surat edaran dari gubernur, yang mendukung penanganan kasus Avian Influenza.

Sebagian besar informan menyatakan hambatan tersebar dalam penanganan flu burung ini adalah masih rendahnya pengetahuan masyarakat tentang bahaya flu burung. Disamping itu hambatan dari pemerintah sendiri, kurangnya dukungan anggaran yang menyebabkan kurang optimalnya kinerja tim.

\section{Saran}

1. Meningkatkan kerja sama dengan lintas program dan lintas sektor didalam penanganan flu burung di tingkat kelurahan, kecamatan, maupun kabupaten/kota.

2. Mengupayakan alokasi anggaran untuk flu burung bagi pukesmas yang belum mendapatkan anggaran dari bantuan luar negeri melalui sharing budget.

3. Pemerintah daerah sebaiknya mengupayakan adanya peraturan daerah yang mengatur tentang tata laksana pemeliharaan unggas, tempat penjualan dan tempat pemotongan unggas, sebab hal tersebut sumber utama terjadinya penularan Avian Influenza bersumber dari hewan/ unggas.

\section{Daftar Pustaka}

Akoso, B.T.2006. Waspada Flu Burung, Penyakit Menular Pada Hewan dan Manusia. Kanisius, Yogyakarta.

Atmawinata, E. 2006. Kiat Bebas Flu Burung. Yrama Widya, Bandung

Anonimus, 2005. Yang Perlu Diketahui tentang Flu Burung. www.Vision.net.id 10 Desember 2005

Atmosukarto, K. et.al. 2000. Pengaruh Lingkungan Pemukiman dalam Penyebaran Penyakit Tuberkulosis. Jakarta

Azwar, A. Prihartono, J. 2003. Metodologi Penelitian Kedokteran dan Kesehatan Masyarakat. Bumirupa Aksara. Jakarta 
Azwar, A. 1995. Pengantar Ilmu Lingkungan. Rineka Cipta. Jakarta

Azwar, A. 1999. Pengantar Epidemiologi Edisi Revisi. Binarupa Aksara. Jakarta

Badan Penelitian dan Pengembangan Depkes RI. 2005. Flu Burung. Jakarta

Bustan, M.N. 2002. Pengantar Epidemiologi. Rineka Cipta, Jakarta

CDC Atlanta, 2007. Pengendalian Fl Burung bagi Juru Bicara dan Tim Hubungan Masyarakat. Depkes RI, Jakarta

Departemen Komunikasi Dan Informatika, Badan Informasi Publik. 2005. Flu Burung Ancaman dan Pencegahan. Jakarta.

Dinas Kesehatan Kabupaten Pelalawan. 2008. Profil Kesehatan Kabupaten Pelalawan tahun 2008. Pangkalan Kerinci

Dinas Kesehatan Kota Pekanbaru. 2008. Profil Kesehatan Kota Pekanbaru tahun 2008. Pekanbaru.

Dinas Kesehatan Provinsi Riau. 2008. Profil Kesehatan tahun 2008. Pekanbaru

Dinas Kesehatan Provinsi Riau, 2009. Laporan kegiatan Rakerkesda 2009. Pekanbaru
Donovan, R.j. H. 2003, Social Marketing Principles and Practise. IP Comunication, Melbourne.

Green, L. W. And Kreuter M. W, 2000. Health Promotion Planning An Educational adn Approach, Second Edition. Mayfield Publishing Company, London

Hutomo, S. 2008. Kandang Unggas Untuk Mengcegah Penularan Penyakit. Deptan Ri, Jakarta

Kristina, Isminaya, dan Leny Wulandari. 2005. Flu Burung. $\quad$ www.Litbang.Depkes.go.id 18 Desember 2005.

Majalah Ilmu Kefarmasian, 2006. Avian Influenza A (H5N1):Patogenesis, Pencegahan dan Penyebaran Pada Manusia. UI Depok

Masjhur, 1998. Manusia, kesehatan, dan Lingkungan Kualitas Hidup Dalam Perspektif Perubahan Lingkungan Global. Alumni, Bandung.

Notoadmojo, S. 2003. Ilmu Kesehatan Masyarakat. Rineka Cipta. Jakarta

Program Pascasarjana Universitas Riau. 2004. Pedoman Penulisan Tesis dan Disertasi. UNRI Press Riau. 